\title{
GC-MS-based metabolic profiling of Escherichia coli exposed to subinhibitory concentration of enoxacin
}

\section{Enoksasin subinhibitör konsantrasyonu maruziyeti altında Escherichia coli'nin GC-MS bazlı metabolomik profillemesi}

\author{
Engin KOÇAK ${ }^{1}$ (ID), Ceren ÖZKUL² (ID)
}

\section{ABSTRACT}

Objective: The rapid development of bacterial resistance to antibiotics is one of the most recent threats to human health. Understanding the metabolism of pathogens is essential to gain insights into the adaptation strategies that are required to deal with the host environment during infection and to identify new drug targets. In recent years omics technologies have offered new routes to understand adaptation and resistance mechanisms of pathogens against antibiotics at molecular level. In present work, we analyzed the metabolic response of Escherichia coli during treatment with enoxacin to identify metabolic adapdation processes.

Methods: Gas chromatography/Mass spectroscopy (GC/MS) based metabolomics approach was used for metabolomics analysis. Metabolites were extracted using methanol: water co-solvent system. After derivatization process, Metabolites separated in GC column and analyzed in MS. MS-DIAL metabolomics and lipidomics platform was performed to analyze raw GC/ MS data. Metabolites were identified with retention index database and quantified relatively between control and enoxacin-treated groups. Statistically

\section{ÖZET}

Amaç: Antibiyotiklere karșı hızla gelișen bakteri direnci insan sağlığını etkileyen en önemli tehlikelerden biri haline gelmiștir. Patojenlerin metabolizmalarının anlașılması konak ortama karșı gerekli metabolik adaptasyonların anlașılmasında ve yeni antimikrobiyal hedeflerin belirlenmesinde oldukça önemlidir. Son yıllarda gelișen omik teknolojiler patojenlerin antibiyotiklere karşı adaptasyon ve direnç süreçlerinin moleküler düzeyde incelenmesinde yeni firsatlar sunmuştur. Bu çalıșmada Escherichia coli'nin enoksasine karșı verdiği metabolik cevabı araștırarak metabolik adaptasyon süreçlerini belirlemeye çalıștık.

Yöntem: Bu çalıșmada metabolomik analiz için gaz kromatografisi/kütle spektroskopisi (GC/MS) bazlı metabolomik yaklașım kullanılmıștır. Metabolitlerin ekstraksiyonunda methanol: su çözücü karıșımı kullanılmıștır. Türevlendirme işlemi sonrasında metabolitler önce GC kolonunda ayrıșmıș daha sonrasında kütle spektroskopisinde analiz edilmiștir. Elde edilen ham GC/MS verilerinin biyoinformatik analizleri için MSDIAL metabolomik ve lipidomik platform kullanılmıștır. Metabolitlerin yapıları alıkonma indeksi veri bankasına göre yapılmıștır. İki grup arasında anlamlı olarak değișen

${ }^{1}$ Health Sciences University, Gulhane Faculty of Pharmacy, Deparment of Analytical Chemistry, Ankara ${ }^{2}$ Hacettepe University, Faculty of Pharmacy, Department of Pharmaceutical Microbiology, Ankara

İletişim / Corresponding Author : Engin KOÇAK

Sağlık Bilimleri Üni., Gülhane Eczacılık Fakültesi, Analitik Kimya AD, Etlik, Ankara - Türkiye E-posta / E-mail : kocakengin@hotmail.com

DOI ID : 10.5505/TurkHijyen.2021.00008

Koçak E, Özkul C. GC-MS-based metabolic profiling of Escherichia coli exposed to subinhibitory concentration of enoxacin. Turk Hij Den Biyol Derg, 2021; 78(3): 307 - 316 
significant altered metabolites were investigated via pathway enrichment analysis.

Results: Metabolite profile of control and enoxacintreated groups were compared to observe cellular adaptation against the antibiotic stress. Principal component analysis of GC/MS results showed that there was a dramatic shift at general metabolome structure under antibiotic stress. We identified 92 metabolites and statistical analysis indicated 36 metabolites altered significantly between experimental groups. Pathway enrichment analysis showed that amino acid biosynthesis, glycine, serine, and threonine metabolism, Aminoacyl-tRNA metabolism, purine metabolism, galactose metabolism was induced in $E$. coli exposed to subinhibitory concentration of enoxacin.

Conclusion: In present study, we investigated metabolic adapdation of $E$. coli against enoxacininduced stress. Our findings may contribute to current literature to expand the understanding of bacteriaantibiotic interactions at metabolome level.

Key Words: Enoxacin, Escherichia coli, GC/MS, Metabolomics metabolitler belirlendikten sonra yolak analizleri ile değerlendirmeler yapılmıștır.

Bulgular: Bu çalıșmada metabolik adaptasyonu anlamak için kontrol ve enoksasin maruziyeti altında bulunan $E$. coli hücrelerinin metabolit profilleri karșılaștırılmıștır. Temel bileșenler analizi (PCA) sonuçları enoksasin maruziyeti altında $E$. coli hücrelerinin metabolit yapısının dramatik șekilde değiștiğini göstermiștir. Yapılan analizlerde toplam 92 metabolitin yapısı aydınlatılmıș ve bunlardan 36 tanesinin istatistiksel olarak anlamlı şekilde değiștiği belirlenmiștir. Miktarı değișen metabolitler yolak analizleri ile değerlendirilmiş ve enoksasin maruziyeti altında aminoasit biyosentezi, aminoaçiltRNA metabolizması, pürin metabolizması, glisin, serin ve treonin metabolizması ve galaktoz metabolizması gibi hücresel süreçlerin farklılaștığı tespit edilmiștir.

Sonuç: Elde edilen sonuçlar enoksasin maruziyeti altında $E$. coli'de meydana gelen metabolik değișiklikleri ve antibiyotik kaynaklı stres koșullarında nasıl adapte olduğu hakkında bilgi sunmaktadır. Yapılan çalıșmanın sonuçları antibiyotik-bakteri ilișkisinin anlașılması ile ilgili olarak literatüre ve gelecek çalıșmalara katkıda bulunacaktır.

Anahtar Kelimeler: Enoksasin, Escherichia coli, GC/MS, Metabolomik

\section{INTRODUCTION}

Antibiotic resistance is one of the most critical problems worldwide. Overpopulation, increasing use of the antibiotics in clinical settings and animal production, wildlife spread are major causes of antibiotic resistance. World health organization (WHO) centers for disease control and prevention (CDC) estimate 700.000 deaths annually worldwide and every country is potentially affected. Moreover, economic impact of resistant bacteria infections is a big challenge for each country. In the USA alone, the total economic burden is estimated $\$ 20$ billion in a year (1).

After the successes of the antibiotic golden age, the discovery rate was decreased, along with an increase in the number of multi drug resistance strains. Today there is a great effort to discover new antibiotics. Many researches analyze antimicrobial properties of semi-synthetic and synthetic molecules. Moreover, target (gene)-based screening and cellbased screening techniques have been used to find new antimicrobial targets in cells and discover candidate molecules $(2,3)$. However, these strategies have not been sufficient to find realistic solution for antibiotic resistant problem. Antibiotic-pathogen interaction has been missing part and gained importance to 
understand mode of action of antibiotics, adaptation and resistance mechanisms of pathogens. The postgenomics technologies (proteomics, transcriptomics and metabolomics) have offered great opportunity to respond to this challenge (4-7). This growing trend could lead to find new routes to overcome resistance problem.

The fluoroquinolones are broad-spectrum antibiotics that have been used in clinical practice for the treatment of infections since 1980s. Their effect over wide range of gram negative and positive bacteria has led to widespread use worldwide. However, fluoroquinolone-resistant strains have emerged and increased dramatically in recent years $(8,9)$. Metabolomics, proteomics and transcriptomics techniques have been used to understand the effect of various members of fluoroquinolones (ciprofloxacin, ofloxacin) over pathogens and also resistance and adaptation mechanisms against the fluoroquinolones (10-12). However, these studies were early steps and there is long way to understand fluoroquinolonebacteria relationship at molecular level. Enoxacin that is a member of fluoroquinolone family has been used for especially urinary tract infections. There is any detailed study about the metabolic adapdation of pathogen against the enoxacin.

In present work, we used gas chromatography/ mass spectroscopy (GC/MS) based metabolomics approach to analyze the change of metabolome structure of $E$. coli under enoxacin stress conditions. Result showed that there was a dramatic shift in metabolome structure and various cellular pathways altered with the effect of enoxacin. We believe that our findings will contribute to understand bacteriaantibiotic relationship and further experiments regarding with fluoroquinolone resistance.

\section{MATERIAL and METHOD}

\section{Bacterial Culture}

E. coli ATCC 25922 was subcultured on Tryptic Soy Agar. In order to confirm the minimum inhibitory concentration (MIC) value of enoxacin against $E$. coli, standard broth microdilution was performed according to the method reported by the Clinical Laboratory Standards Institute (CLSI). The MIC value of enoxacin was determined and compared with the latest breakpoint tables of EUCAST. For metabolomics experiments, subinhibitory concentration (half of the MIC) enoxacin was used. E. coli ATCC 25922 was cultured on Mueller Hinton Broth (MHB) and incubated under $37^{\circ} \mathrm{C}$ until the log phase was achieved. The bacterial suspension was prepared using MHB that contained the MIC/ 2 value of enoxacin to obtain a bacterial concentration of $5 \times 105 \mathrm{cfu} / \mathrm{ml}$ bacteria. The same concentration of bacterial culture under same conditions was also prepared without adding any antibiotic. Flasks were incubated at $37^{\circ} \mathrm{C}$ for 20 h. Experiments were performed with three replicates.

\section{Extraction of Metabolites}

After centrifugation the cell pellets were washed by phosphate buffer saline (PBS) twice. In present work, we used enzymatic lysis procedure, we used lysozyme for enzymatically disruption. Incubation time was set to 30 minutes. Methanol:Water ( $9: 1 \mathrm{v} / \mathrm{v})$ co-solvent system was used for metabolite extraction from cellular lysate. $850 \mu \mathrm{L}$ extraction solvent added to $150 \mu \mathrm{L}$ sample and mixed in a vortex for $1 \mathrm{~min}$. Samples were centrifuged at $15.000 \mathrm{~g}$ for 10 minutes. Supernatant were taken and carefully evaporated under vacuum centrifuge.

In derivatization process, firstly $20 \mu \mathrm{L}$ methoxyamine solution in pyridine $(20 \mathrm{mg} / \mathrm{ml})$ (Sigma) was added to the dried extract and incubated at $70^{\circ} \mathrm{C}$ for $90 \mathrm{~min}$. In second step, $100 \mu$ of MSTFA (sigma) was added and incubated at $37^{\circ} \mathrm{C}$ for 30 minutes. After derivatization, samples were transferred to auto sampler vials for GC/MS analysis.

\section{GC/MS conditions}

Gas chromatography-mass spectrometry (GCMS)-based metabolomics analysis was performed as described previously (13). Metabolites were analyzed 
using GC-MS (Shimadzu GCMS-QP2010 Ultra) with a DB5 MS stationary phase column $(30 \mathrm{~m}+10 \mathrm{~m}$ DuraGuard $\mathrm{x}$ $0.25 \mathrm{~mm}$ i.d. and $0.25-\mu \mathrm{m}$ film thickness). Helium was used as the carrier gas at $1 \mathrm{ml} / \mathrm{min}$ flow rate. Samples were injected in non-split mode. Injection volume was adjusted at $2 \mu \mathrm{l}$. The injector temperature was held at $250^{\circ} \mathrm{C}$. In gradient system, oven temperature was fixed at $70^{\circ} \mathrm{C}$ for one minute, then increasing up to $325^{\circ} \mathrm{C}$ by $10^{\circ} \mathrm{C} / \mathrm{min}$ gradient and held for 10 minutes at $325^{\circ} \mathrm{C}$. Total separation time was 37.5 minutes. The MS detector was performed at El mode. Data acquisition was performed in full scan mode with mass range between $50-650 \mathrm{~m} / \mathrm{z}$.

\section{GC/MS Data Processing}

Raw GC/MS data was processed in MS-DIAL (version 3.96) metabolomics and lipidomics platform (http://prime.psc.riken.jp/Metabolomics_Software/ MS-DIAL/). In MS-DIAL settings, mass range was between 0-1000 Da. Minimum peak height for peak detection was 1000 amplitude. Retention time tolerance was $1 \mathrm{~min}$. Identification score cut off was $60 \%$. We used GC/MS all public Kovats retention index database (15302 records)(http://prime.psc.riken.jp/ Metabolomics_Software/MS-DIAL/) for metabolite identification. Peak areas of metabolites were calculated in MS-DIAL and normalized according to total ion chromatogram. Metaboanalyst 4.0 platform was used for statistical analysis. Volcano plot analysis was applied to find altered metabolites (Fold change $>1.5$ and $p$ vaue $<0.05$ ). Altered metabolites were analyzed in pathway module in metaboanalyst 4.0 (https://www.metaboanalyst.ca) and KEGG database (https://www.genome.jp/kegg/pathway.html).

\section{RESULTS}

The MIC value of enoxacin against $E$. coli ATCC 25922 was $0.12 \mu \mathrm{g} / \mathrm{ml}$, which was within the expected susceptibility range. Thus the half of the MIC value $(0.06 \mu \mathrm{g} / \mathrm{ml})$ was used for further metabolomics studies.
In metabolomics analysis, extracted metabolites were analyzed in GC/MS system. Base peak chromatograms of control and enoxacin treated groups were given in supplementary information. Raw GC/MS data was processed in MS-DIAL software. We detected 930 features and identified 92 metabolites. Peak intensities were calculated and normalized according to total ion chromatogram (TIC). Metaboanalyst 4.0 platform was used for statistical analysis.

We focused on principal component analysis (PCA) to observe general metabolic changes with the effect of enoxacin and results showed that there was a dramatic shift in metabolome structure under stress conditions (Figure 1A). Volcano plot analysis was applied to find altered metabolites (Fold change $>1.5$ and $p$ vaue $<0.05$ ) (Figure $1 \mathrm{~B}$ ). We observed that 36 differentially expressed metabolites were detected between control and enoxacin treated groups including 22 upregulated and 16 downregulated metabolites, respectively (supplementary information).

Altered metabolites were evaluated in Metaboanalyst 4.0 (pathway analysis module) and KEGG mapper platform to understand systematic effect of enoxacin over $E$. coli (Figure 2).

\section{DISCUSSION and CONCLUSION}

In present work, extracted metabolites from control and enoxacin treated groups were analyzed with GC/MS based metabolomics analysis. PCA analysis showed that there is a dramatic shift in metabolome structure of $E$. coli under enoxacin stress. Metabolome structure is very dynamic and environmental stress could trigger many biological processes simultaneously and PCA indicated that antibiotic induced stress leads deep impact over cellular metabolism.

Statistical analysis showed that 36 metabolites altered between two experimental groups ( $p$ value $<0.05$ and fold change $>1.5$ ). Altered metabolites were evaluated in pathway analysis in metaboanalyst 
A.

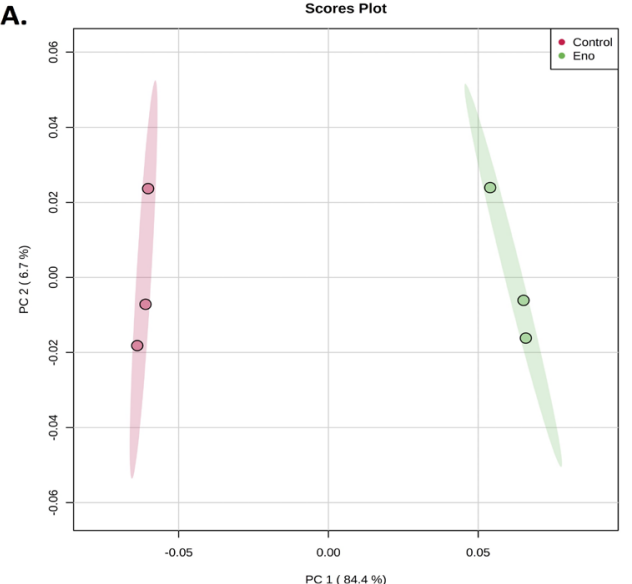

B.

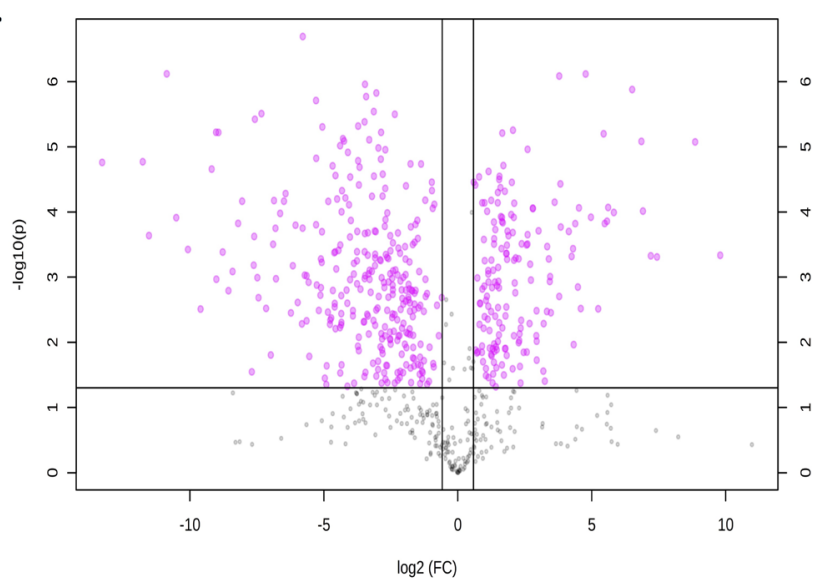

Figure 1. A) Principal component analysis of control and enoxacin treated groups.

B) Volcano plot analysis of features (Pink dots indicate significantly altered features between two experimental groups)
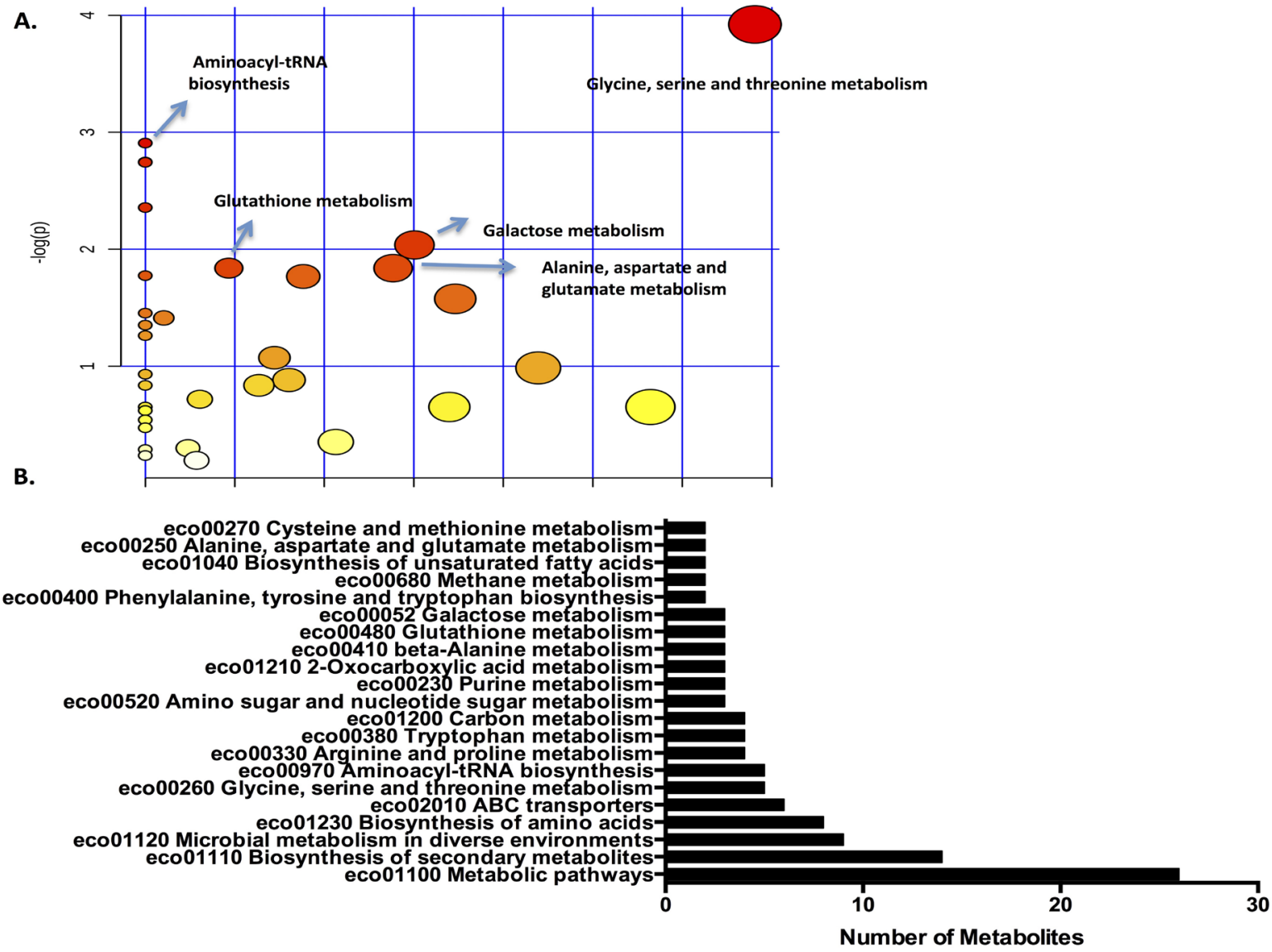

Figure 2. Induced pathways under enoxacin stress.

A) Pathway analysis module in Metaboanalyst 4.0

B) KEGG mapper database. 
4.0 and KEGG database to explain metabolic changes.

Changes in metabolic pathways within E. coli

Amino acids, referred to as the building blocks of proteins, are compounds that play many critical roles in cells. Studies showed that amino acid biosynthesis is one of the key parameter for cell growth, pathogenicity, biofilm-formation $(14,15)$. Moreover, various proteomics, metabolomics and transcriptomics studies revealed that this pathway is changed dramatically under antibiotic stress (10, 16-18). Zampieri et. al. showed that amino acid biosynthesis is the most affected pathway in $E$. coli at early phase of antibiotic stress and it has direct connection to general antibiotic- stressresponse. In present work, we observed that amino acid metabolism was changed under enoxacin stress condition. Most of the altered metabolites were up regulated in enoxacin treated group (Figure $3 \mathrm{~A}$ ). This biological process could be one of the key steps in adaptation process.

Glycine, serine, and threonine metabolism was also one of the most significant pathways. Cheng. et al., showed that glycine, serine and threonine pathway altered between resistant and sensitive strains of $E$. coli isolates (19). Also Ye et al, used
LC/MS based proteomics approach and showed that glycine, serine and threonine pathway was one of the most important regulatory mechanisms (20). Schelli et al, used comparative metabolomics analysis to understand metabolic adaptation in Staphylococcus aureus under the effect of various antibiotics and they observed that glycine, serine, and threonine metabolism was significantly different (21). In present work, we found similar results with this pathway (Figure 3B). There is no detailed mechanistic study role of glycine, serine and threonine metabolism with metabolic adaptation process. In further experiments, targeted studies could response to this question.

Aminoacyl-tRNA metabolism is very important in protein biosynthesis and cell envelope. Previous studies have indicated that some antibacterial quinolones induce bacterial aminoacyl-tRNA synthetase (ARS) $(10,22)$. In pathway analysis, we observed that glycinine (downregulated), L-alanine (upregulated), L-tryptophan (upregulated), L-threonine (upregulated) and phosphoserine (downregulated) were involved in Aminoacyl-tRNA biosynthesis (Figure 3). Changes in Aminoacyl-tRNA metabolism could demonstrate differentiation in translation process.

A.

Enoxcacin treated

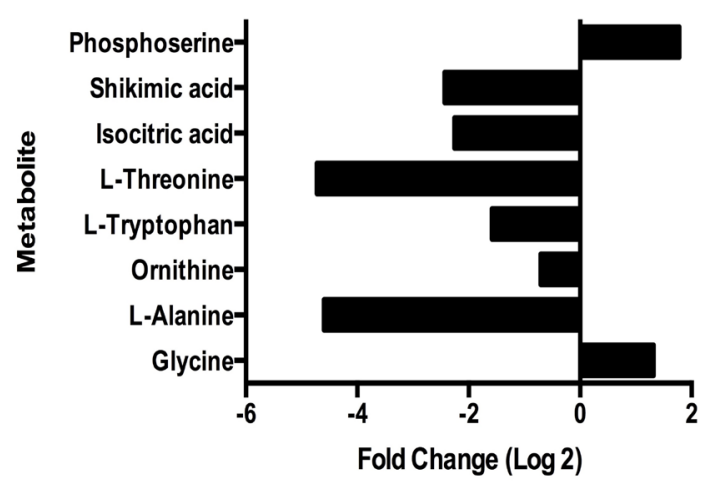

Control

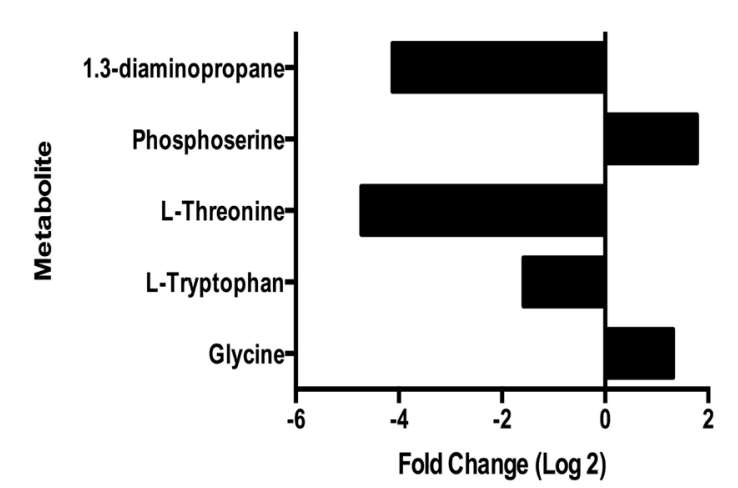

B.

Figure 3. Fold changes of metabolites in

A) Amino acid biosynthesis,

B) glycine, serine, and threonine metabolism 
Purine and pyrimidine nucleotides are major energy carriers, subunits of nucleic acids and precursors for the synthesis of nucleotide cofactors. In literature, there has been growing evidence regarding with alteration of purine metabolism under antibiotic stress. Zampieri et al, showed that purine metabolism was one of the most affected cellular process in early phase of antibiotic stress for $E$. coli (18). Dorries et al, observed similar results for Staphylococcus aureus with metabolomics analysis. They found that most of the metabolites purine metabolism was up regulated under ciprofloxacin stress but they found purine metabolism was down regulated under vamcomycin and ampicillin treated groups (23). All these data suggested that purine metabolism play important role in resistance and adaptation process. Various
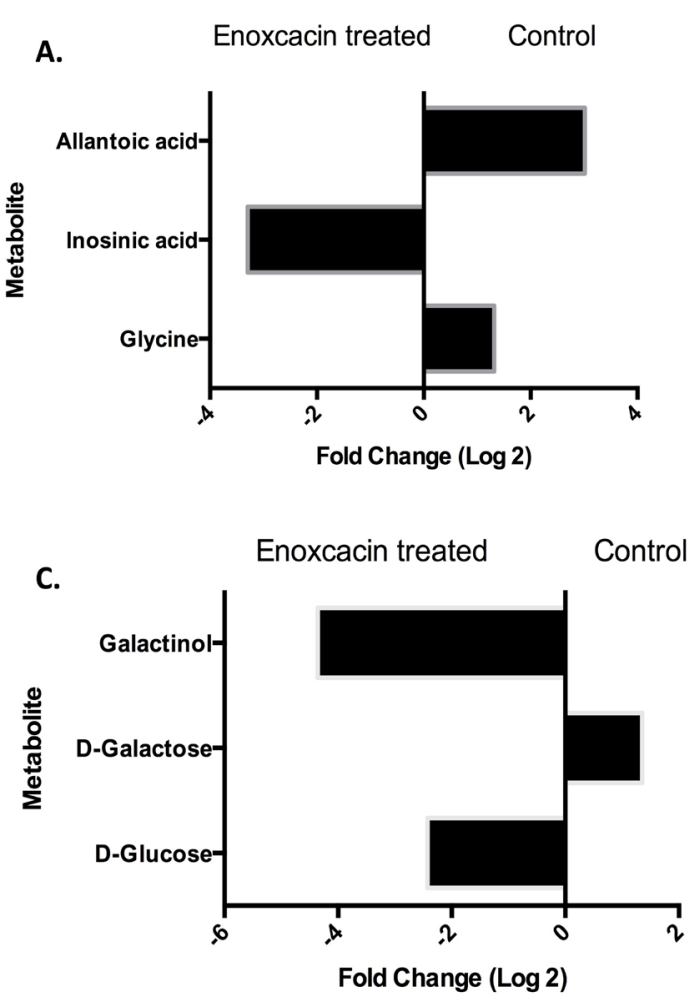

Figure 2. Fold change of metabolites in

A) Purine metabolism,

B) Glutathione metabolism,

C) Galactose metabolism,

D) Alanine, aspartate and glutamate biosynthesis metabolites in purine metabolism were altered under enoxacin stress (Figure 4A).

The cellular antioxidant mechanism plays critical role in antibiotic resistance against the reactive oxygen species (ROS). Glutathione metabolism is the key system in defense system against ROS species and very important for cell growth and survival. In previous studies, it was showed that glutathione metabolism plays important role in antibiotic resistance process (24). In present work, we found that various metabolites altered in enoxacin-treated group (Figure 4B). Moreover, we observed that expression level of spermin increased dramatically. Spermine, which is in glutathione metabolism, is a member of polyamines, which are polycationic molecules, produced through complex pathways.
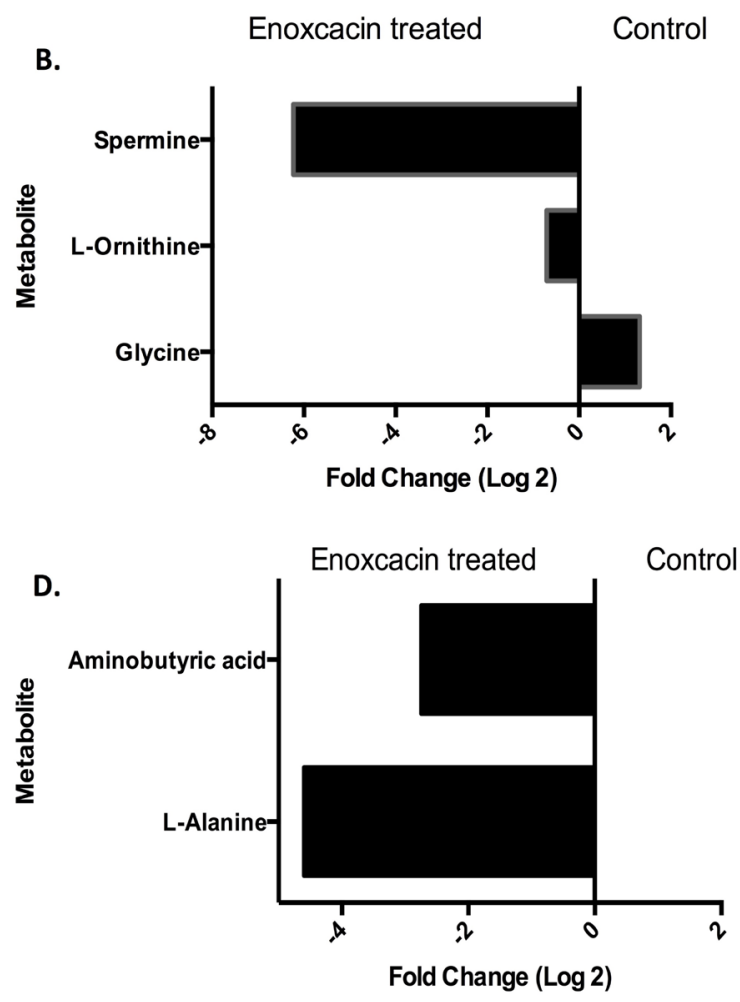
Polyamines involve in a wide range of biological processes. The interactions between polyamines and porins were defined in recent years. Porin proteins are main regulators for overall permeability of the outer membrane. Lyer et al, showed that four polyamines (spermine, spermidine, cadaverine and putrescine) were very effective on the activity of porin proteins (25). These polyamines suppress channel opening and promote the inactive state. Sarathy et al, showed that polyamines induced membrane permeability via affecting porin proteins. (26). They found that polyamines decreased membrane permeability of the outer membrane, which leads to decreased intake of fluoroquinolones in Mycobacteria. In our work, increasing level of spermine may lead to membrane based-resistance against enoxacin.

Galactose metabolism, is also known as Leloir pathway, is very important for energy production, protein glycosylation, LPS biosynthesis and virulence (27). Chai. et al, showed that galactose metabolism played essential role $n$ biofilm formation (28). Yang et al, analyzed general carbon metabolism of $E$. coli under doxycycline stress (29). They showed that expression level of genes in galactose metabolism were significantly different from control group. In present work, we found that three metabolite in this pathway altered under enoxacin stress (Figure 4C).

Alanine, aspartate and glutamate biosynthesis is another important metabolic pathway. In previous studies showed that this pathway altered under antibiotic stress conditions $(30,31)$. In present work, we observed that various metabolites in this pathway altered significantly (Figure 4D).

In conclusion, antimicrobial resistance is one of the most important global problems. Understanding of antibiotic-pathogen relationship at molecular level could give opportunity to discover new antibiotics and treatment methods. In present work, we investigated altered metabolome structure of $E$. coli with GC/MS based metabolomics approach. Results showed that various metabolic pathways altered simultaneously under enoxacin stress. We believe that our results will contribute to understand antibiotic-pathogen relationship.

\section{ETHICS COMITTEE APPROVAL}

* This study does not require Ethics Committee Approval.

\section{CONFLICT OF INTEREST}

The authors declare no conflict of interest. 


\section{REFERENCES}

1. Golkar Z, Bagasra O, Pace DG. Bacteriophage therapy: a potential solution for the antibiotic resistance crisis. J Infect Dev Ctries. 2014;8(2):12936.

2. Mills SD. When will the genomics investment pay off for antibacterial discovery? Biochem Pharmacol. 2006;71(7):1096-102.

3. Moloney MG. Natural Products as a Source for Novel Antibiotics. Trends Pharmacol Sci. 2016;37(8):689701.

4. McGettigan PA. Transcriptomics in the RNA-seq era. Curr Opin Chem Biol. 2013;17(1):4-11.

5. Pulido MR, Garcia-Quintanilla M, Gil-Marques ML, McConnell MJ. Identifying targets for antibiotic development using omics technologies. Drug Discov Today. 2016;21(3):465-72.

6. Vranakis I, Goniotakis I, Psaroulaki A, Sandalakis V, Tselentis Y, Gevaert K, et al. Proteome studies of bacterial antibiotic resistance mechanisms. J Proteomics. 2014;97:88-99.

7. Hoerr V, Duggan GE, Zbytnuik L, Poon KK, Grosse $C$, Neugebauer $U$, et al. Characterization and prediction of the mechanism of action of antibiotics through NMR metabolomics. BMC Microbiol. 2016;16:82.

8. Redgrave LS, Sutton SB, Webber MA, Piddock LJ. Fluoroquinolone resistance: mechanisms, impact on bacteria, and role in evolutionary success. Trends Microbiol. 2014;22(8):438-45.

9. Thabet L, Memmi M, Turki A, Messadi AA. The impact of fluoroquinolones use on antibiotic resistance in an intensive care burn department. Tunis Med. 2010;88(10):696-9.

10. Li W, Zhang S, Wang X, Yu J, Li Z, Lin W, et al. Systematically integrated metabonomic-proteomic studies of Escherichia coli under ciprofloxacin stress. J Proteomics. 2018;179:61-70.

11. Erickson KE, Otoupal PB, Chatterjee A. Transcriptome-Level Signatures in Gene Expression and Gene Expression Variability during Bacterial Adaptive Evolution. mSphere. 2017;2(1).
12. Patkari M, Mehra S. Transcriptomic study of ciprofloxacin resistance in Streptomyces coelicolor A3(2). Mol Biosyst. 2013;9(12):3101-16.

13. Gonulalan EM, Nemutlu E, Bayazeid O, Kocak E, Yalcin FN, Demirezer LO. Metabolomics and proteomics profiles of some medicinal plants and correlation with BDNF activity. Phytomedicine. 2019:152920.

14. Lu H, Que Y, Wu X, Guan T, Guo H. Metabolomics deciphered metabolic reprogramming required for biofilm formation. Sci Rep. 2019;9(1):13160.

15. Li T, Zhan Z, Lin $Y$, Lin $M$, Xie $Q$, Chen $Y$, et al. Biosynthesis of amino acids in xanthomonas oryzae pv. oryzae is essential to Its pathogenicity. Microorganisms. 2019;7(12).

16. Le CF, Gudimella R, Razali R, Manikam R, Sekaran SD. Transcriptome analysis of Streptococcus pneumoniae treated with the designed antimicrobial peptides, DM3. Sci Rep. 2016;6:26828.

17. Maass S, Otto A, Albrecht D, Riedel K, TrautweinSchult A, Becher D. Proteomic signatures of Clostridium difficile stressed with metronidazole, vancomycin, or fidaxomicin. Cells. 2018;7(11).

18. Zampieri M, Zimmermann M, Claassen M, Sauer U. Nontargeted metabolomics reveals the multilevel response to antibiotic perturbations. Cell Rep. 2017;19(6):1214-28.

19. Cheng ZX, Guo C, Chen ZG, Yang TC, Zhang JY, Wang $\mathrm{J}$, et al. Glycine, serine and threonine metabolism confounds efficacy of complement-mediated killing. Nat Commun. 2019;10(1):3325.

20. Ye JZ, Lin XM, Cheng ZX, Su YB, Li WX, Ali FM, et al. Identification and efficacy of glycine, serine and threonine metabolism in potentiating kanamycinmediated killing of Edwardsiella piscicida. J Proteomics. 2018;183:34-44.

21. Schelli K, Zhong F, Zhu J. Comparative metabolomics revealing Staphylococcus aureus metabolic response to different antibiotics. Microb Biotechnol. 2017;10(6):1764-74. 
22. Kim S, Lee SW, Choi EC, Choi SY. AminoacyltRNA synthetases and their inhibitors as a nove family of antibiotics. Appl Microbiol Biotechnol. 2003;61(4):278-88.

23. Dorries K, Schlueter R, Lalk M. Impact of antibiotics with various target sites on the metabolome of Staphylococcus aureus. Antimicrob Agents Chemother. 2014;58(12):7151-63.

24. Cameron JC, Pakrasi HB. Glutathione facilitates antibiotic resistance and photosystem I stability during exposure to gentamicin in cyanobacteria. Appl Environ Microbiol. 2011;77(10):3547-50.

25. Iyer R, Delcour AH. Complex inhibition of OmpF and OmpC bacterial porins by polyamines. J Biol Chem. 1997;272(30):18595-601.

26. Sarathy JP, Lee E, Dartois V. Polyamines inhibit porin-mediated fluoroquinolone uptake in mycobacteria. PLoS One. 2013;8(6):e65806.

27. Carlson-Banning KM, Chou A, Liu Z, Hamill RJ, Song $\mathrm{Y}$, Zechiedrich L. Toward repurposing ciclopirox as an antibiotic against drug-resistant Acinetobacter baumannii, Escherichia coli, and Klebsiella pneumoniae. PLoS One. 2013;8(7):e69646.
28. Chai $Y$, Beauregard PB, Vlamakis H, Losick R, Kolter R. Galactose metabolism plays a crucial role in biofilm formation by Bacillus subtilis. mBio. 2012;3(4):e00184-12.

29. Yang $Y$, Mi J, Liang J, Liao X, Ma B, Zou Y, et al. Changes in the carbon metabolism of Escherichia coli during the evolution of doxycycline resistance. Front Microbiol. 2019;10:2506.

30. Lin X, Kang L, Li H, Peng X. Fluctuation of multiple metabolic pathways is required for Escherichia coli in response to chlortetracycline stress. Mol Biosyst. 2014;10(4):901-8.

31. Su YB, Peng B, Li H, Cheng ZX, Zhang TT, Zhu JX, et al. Pyruvate cycle increases aminoglycoside efficacy and provides respiratory energy in bacteria. Proc Natl Acad Sci U S A. 2018;115(7):E1578-E87. 